\title{
Psychospiritual analysis and appreciation of Vincent van Gogh
}

\begin{abstract}
Book Title:
Bone Dead and Rising, Vincent Van Gogh and the Self Before God

Book Cover:

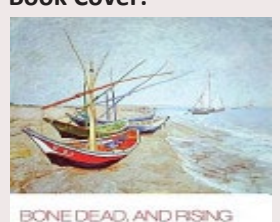

BONEDEAD, AND FISANC:

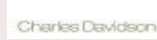

Author:

Charles Davidson

ISBN:

160608616

Publisher:

Wipf and Stock - Cascade

Books, Eugene, OR, 2011

p. $276, \$ 28.00 *$

*Book price at time of Review

-

Review Title:

Psychospiritual analysis and appreciation of Vincent van Gogh

Reviewer:

J. Harold Ellens ${ }^{1,2}$

\section{Affiliations:}

${ }^{1}$ Department of Near

Eastern Studies, University

of Michigan, United States

${ }^{2}$ Faculty of Theology,

University of Pretoria,

South Africa

Email:

jharoldellens@juno.com

Postal address:

26705 Farmington,

Farmington Hills, MI 48334,

United States
\end{abstract}

(C) 2011. The Authors.

Licensee: AOSIS

OpenJournals. This work

is licensed under the

Creative Commons

Attribution License.
The Reverend Dr Charles Davidson is a retired Presbyterian preacher and notable Pastoral Theologian. He has given us a volume of psychospiritual analysis and appreciation of the person, life, and work of one of the world's greatest artists. Vincent van Gogh's art is the expression of a deeply sensitive soul working uncompromisingly at the aggressive search for life's authentic meaning as lived out before the face of God. Van Gogh repudiated the scholasticism of 18 th and 19th century Reformed Theology, the brazen racism and elitism of the caste structured Dutch culture, and the inauthenticity of the church's claims to represent Christ whilst it hid away in its wealthy and carefully disguised Bourgeois patriarchalism. Vincent would have none of it. Like Jesus Christ, he would not back down on his radical notion of universal and unconditional divine grace, considered rank heresy in his theological tradition. That quest sickened and exhausted him, and like Christ, in that quest he died.

Charles Davidson's book tells the story through the lens of psychological assessment and spiritual inquiry. Davidson is the person to craft that kind of an appreciation of this incredible artist's ordeal, and its phenomenal productivity in art as the expression of a tortured psyche and a suffering soul. This book is as much a volume of poignant poetry as of delightfully crafted prose. This lovely volume is such a definitive description of Van Gogh that all future research on this artist will need to begin and end in the profound insights and the poetic expressions of Charles Davidson. Moreover, the book is beautifully presented by the publisher, with 33 prints of Van Gogh's paintings and photos of his family members, a full color painting on the front cover, an excellent bibliography, and indexes of subjects, scripture references, and all of Van Gogh's paintings. Here we have consummate and definitive scholarship that reads like a novel. Chapters five and six are heavy going through the usual psychoanalytic swamps one must navigate in a study like this, but otherwise once you have taken up this volume it is impossible to put the book down.

Lallene J. Rector of Garrett-Evangelical Theological Seminary wrote the Preface. This is followed by the author's Prologue and eight substantive chapters, the titles of which alert us to the various stages of Van Gogh's life and quest: "A Lark in the Sky", "A Risky Affair", "Such a Nobody", "The Prodigal", "The Artist Before God", "Art as Intimation of the Divine", "The Art of Being the Self Before God", and "This Holy 'Madness". These are followed by an Epilogue, an Appendix ("Chronology of the Life of Vincent van Gogh"), and the aforementioned end papers. The first four chapters form Part One, entitled The "Birth of an Artist". Part Two is called "The Artist within the Art"; both most aptly named.

The specific thrust of this analysis of Van Gogh's ordeal emphasises that the artist's struggle with life is readily understandable given the uncompromising spirit of his quest for authenticity; and the false, inauthentic, and self-aggrandising values of his church, society, and culture. Davidson implies that any one of us with the creativity and courage of Van Gogh, the sensitivity and authenticity of his spirit, subjected to the same compromising pressures, would have the same reaction of ambivalence, alienation, rejection, and identification with those disenfranchised by the religious and secular culture of the time. Van Gogh, like Frost, had a 'lover's quarrel with his world'; but he was not as pragmatically American as Robert Frost. Van Gogh was Dutch: a hard-headed Dutchman in a culture and church that he found to be too hard-headed to be real and genuinely decent or Christian. He desperately needed the love, endorsement, affirmation, esteem, and support of his family, church, and society, but he would not buy it at the cost of what he considered to be any concession that compromised the utter integrity of his personal faith and value system.

This life at cross-grain to all that everyone else seemed to stand for and insist upon often placed Van Gogh in what looked like quasi-psychotic postures. Perhaps he had some episodes in which he crossed the line into active psychosis. In contrast to the history of research that assigns Van Gogh to sainthood (Postema, Space for God) or insanity (most psychoanalytic evaluations), Davidson is sensitive about the fine line that lies between the profound humans suffering of a soul in the

How to cite this book review: Ellens, J.H., 2011, 'Psychospiritual analysis and appreciation of Vincent van Gogh', HTS Teologiese Studies/Theological Studies 67(3), Art. \#1144, 2 pages. http://dx.doi.org/10.4102/hts.v67i3.1144 
distress of grief beyond our imagination, deprivation beyond what we are willing to face straight on, loneliness that is inexpressible, alienation and rejection beyond redemption, on the one hand, and toying around the edges of psychosis, on the other. Where is psychic pain so indescribable that coping with it looks like a slide into alternative reality? None of us can know that unless we have been there and done that. In that place of human extremity labels are easy. Authentic descriptive definitions are impossible. Diagnosis is better set aside there. Empathy counts. Davidson has seen that and given us a wonderful book about how to do that. I assure you, you will not wish to miss this volume.
The noted writer, Frederick Buechner, declared:

This richly detailed and deeply felt account of van Gogh's tormented ... life, together with many telling quotations from his correspondence with his faithful brother, Theo, will be essential reading for all who see him as one of the geniuses of the nineteenth century.

Cliff Edwards adds:

The flow of the narrative and the presence of theological and psychological motifs help us re-vision the artist in a postmodern framework that opens new and creative channels for understanding. 